\title{
第一原理計算によるレーザー加工初期過程解明
}

\author{
矢花一浩 \\ 筑波大学 計算科学研究センター(テ305-8577 茨城県つくば市天王台1-1-1)
}

\section{First-Principles Calculations Exploring Initial Stage of Laser Processing}

\author{
Kazuhiro YABANA \\ Center for Computational Sciences, University of Tsukuba, 1-1-1 Tennodai, Tsukuba, Ibaraki 305-8577
}

(Received August 14, 2016)

\begin{abstract}
We develop a first-principles computational approach for dynamics of electrons and optical fields in crystalline solids that will be useful to explore initial stages of nonthermal laser processing of dielectrics. In the method, we describe atomic-scale electron dynamics in dielectrics induced by an intense and ultrashort laser pulse based on time-dependent density functional theory. Combining the electron dynamics calculation with Maxwell equations that describe propagation of the laser pulse, we evaluate the energy transfer from the laser pulse to electrons in the dielectrics without any empirical parameters. Comparing the energy transfer with the cohesive energy and the heat of fusion of the dielectrics, we estimate threshold and depth of laser ablation.
\end{abstract}

Key Words: Laser processing, First-principles calculation

1.はじめに

物質構造の解明や材料設計など物質科学の諸分野で, 経験的なパラメー夕を全く用いることのない第一原理計 算の方法は今日必須の役割を果たしている。その中軸を 担うのが密度沉関数理論であるが，これは電子基底状態 を記述するものであるため, 光電場が誘起する電子ダイ ナミクスが本質的に重要となる光科学の諸現象には直接 応用することができない. 1990年代から，電子ダイナミ クスを記述するように拡張された時間依存密度汎関数理 論 (Time-dependent density functional theory: TDDFT) が発 展し ${ }^{1)}$, 特に分子の電子励起状態の記述に大きな成功を 収めるようになった2).

我々のグループでは，TDDFTの基礎方程式である時 間依存コーン・シャム (Time-dependent Kohn-Sham: TDKS) 方程式を実時間で解く方法を発展させてきた ${ }^{3-5)}$ 。この 方法を用いると, TDKS方程式に光電場の効果を外場ポ テンシャルとして加えることにより，パルス光が原子 . 分子・固体に照射した時に起こる電子ダイナミクスを経 験的なパラメー夕を用いることなく計算することが可能 になる，固体の単位セル中の電子ダイナミクスに対する TDDFT計算 ${ }^{4)}$ では，光電場を印加した時に起こる原子ス ケールでの電子密度や電流密度の時間変化, そして巨視 的な量である分極, 電子励起エネルギー, 電子・ホール 密度などの情報が得られる。

このTDDFTによる記述は, 超短パルス光が照射して
から数十フェムト秒程度までの, 短い時間スケールでの 電子ダイナミクスに限られている。 また基本的に固体の バンド計算を時間領域に拡張した枠組みであることか ら，アバランシェ過程を引き起こす電子間のあらわな衝 突効果は取り入れられていない。電子と原子運動(フォ ノン)の相互作用に関しては，これまでコヒーレント フォノンの生成過程に対する応用がなされているが(6), 電子から多様なフォノンへのエネルギー移行はまだ調べ られていない.

我々はさらに，上記のナノメートル以下の空間スケー ルを持つ電子ダイナミクス計算と, マイクロメートル程 度の波長を持つパルス光の電磁場に対するマクスウェル 方程式を結合した計算を行うことにより，誘電体中の光 波と電子のダイナミクスを首尾一貫して取り扱うことの できる枠組みを開発した7)。この方法を用いると，誘電 体表面からの距離に応じたパルス光から誘電体中の電子 へのエネルギー移行を求めることが可能となる.

パルス光から物質電子へのエネルギー移行は, レー ザー加工の初期過程を理解する上で最も基本的な情報で ある。特にフェムト秒レーザーを用いた非熱加工では, このエネルギー移行の様相が加工の最終的な形状に強く 反映すると考えられる。一方，エネルギー移行により物 質が変化し，実際に加工が進むには，電子から原子に工 ネルギーが移り原子が移動するまで，ピコ秒よりも長い 時間を要する。この長い時間スケールの現象の記述に は，本稿で紹介するものとは別の理論の枠組みが必要と 
なるが，本稿の結果はその初期条件を与える.

本稿ではまず, 結晶の単位セル内で起こる電子ダイナ ミクスの計算法と例を示し, 次に光波と電子のダイナミ クスを同時に記述する枠組みと計算例を紹介する。その 後に最近我々の行った， $\alpha$ クォーツ $\left(\mathrm{SiO}_{2}\right)$ でのパルス光 から物質電子へのエネルギー移行計算と, その結果を用 いたアブレーションのしきい值強度, 表面からの深さに 対する評価を示す。

\section{2. 単位セル中の電子ダイナミクス計算}

\section{1 時間に依存するバンド計算}

物質構造の第一原理計算で中心となるバンド計算で は, 周期的な電子軌道関数 $u_{\mathrm{nk}}(r)-$ ブロッホ関数 - と, そのエネルギー固有值 $\varepsilon_{\mathrm{nk}}$ を求める。 よく目にするバン ド図は, このエネルギー固有值 $\varepsilon_{\mathrm{nk}}$ を波数 $k$ の関数として 図示したものである。我々は, このバンド計算を時間領 域に拡張することにより, 電子ダイナミクスの第一原理 計算を行う ${ }^{4)}$

レーザーの波長は, 結晶の単位セルの辺の長さと比べ て十分に長いので, 単位セルの中で光電場は一様である と考えることができる(長波長近似).

この空間的に一様で時間とともに変化する電場 $E(t)$ をえるべクトルポテンンシャルを $A(t)$ と書く. $E(t) \equiv-(1 / c) d A(t) / d t$ であ. この電場のもとで時間と ともに変化するブロッホ関数 $u_{\mathrm{nk}}(r, t)$ に対するTDKS方程 式は,

$$
i \hbar \frac{\partial}{\partial t} u_{\mathrm{nk}}(r, t)=\left[\frac{1}{2 m}\left(p+\hbar k+\frac{e}{c} A(t)\right)^{2}+V\right] u_{\mathrm{nk}}(r, t)
$$

で与えられる。ここで，Vは結晶の空間周期性を持つポ テンシャルである。通常のバンド計算で得られる電子基 底状態を初期状態として(1)式を解くことによりパルス 電場を印加した後の時間とともに変化するブロッホ関数 $u_{\mathrm{nk}}(r, t)$ を計算し, 電子密度や電流の時間発展を求める ことができる。

\section{2 シリコン結晶中の電子ダイナミクス計算}

例として，シリコンの結晶にパルス電場を印加した場 合の電子ダイナミクス計算の結果を示そう。シリコン原 子の位置は固定し, フォノンを介した励起は考慮しない ことにする。すると電子励起は，同じ波数を持つ状態間 で，直接バンドギャップのエネルギー $(3.4 \mathrm{eV})$ を越える ことで起こる. Fig. 1(a)は, 印加した電場の時間波形を 示す. 電場の最大強度は $1.23 \mathrm{~V} / \mathrm{nm}$, 平均の振動数は $1.55 \mathrm{eV}$, パルス長 (FWHM) は7 fsにとっている。（b) は単位セル を流れる空間平均をとった電流 (巨視的電流)，(c)はパ ルス電場によりもたらされた 1 原子あたりの電子励起工 ネルギー，(d) は電子・ホール対の密度を表している。

(c) と (d)では, パルス電場の印加中にエネルギーや電 子.ホール対密度の振動が見られる。 これは, パルス光 が通過すると消失するバーチャルな励起に起因する。一 方, 電場が終わった後も持続している励起は, 直接バン

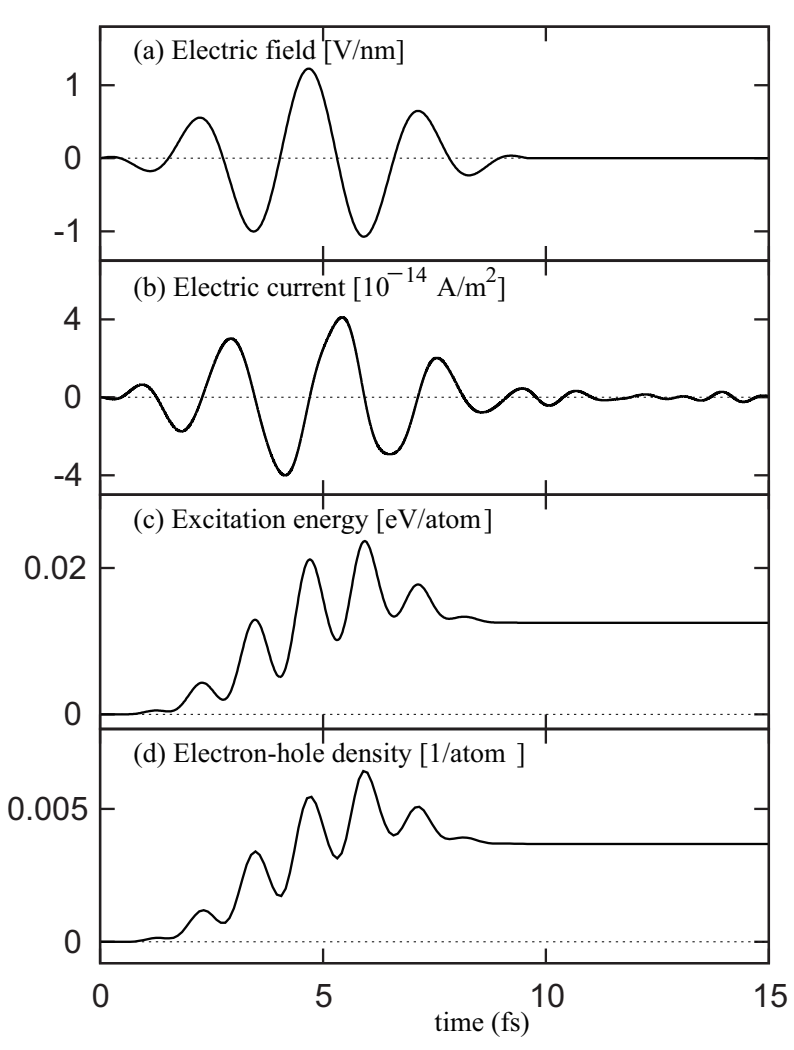

Fig. 1 Time profiles of (a) applied electric field, (b) induced current, (c) electronic excitation energy, and (d) number density of electron-hole pairs when a pulsed electric field is applied to electrons in a unit cell of crystalline silicon.

ドギャップを越えた2光子以上の吸収による実励起によ るものである.

Fig. 2に, 電子の密度分布の時間変化を示す。これは, 振動数とパルス長はFig. 1と同一であるが, 電場の最大 強度はより大きい27.5 V/nmの場合である。（a）は，シリ コンの基底状態における(110)面の電子密度を示してい る。丸印がシリコン原子の位置であり，シリコン原子の 間に価電子が高い密度で存在している。（b)は，パルス 電場が印加されている最中の電子密度を表している。 上 下方向に向いた電場により，シリコン原子間の価電子が 上下に振動している様子がうかがえる。（c）は，パルス 電場が終了した後の電子密度を示している。シリコン原 子間の電子密度が減少し, ボンドが切れている，強い光 電場による電子励起のため, シリコン原子間の価電子が 空隙領域に移動し拡散したことを示している。

\section{3. 光電磁場と電子ダイナミクスの多階層連結計算}

3.1 構成関係式としての電子ダイナミクス計算 パルスレーザー光の物質中の伝播は，巨視的マクス ウェル方程式を用いて記述される. 巨視的電磁気学で は, 物質の性質は分極 $P(t)$ と電場 $E(t)$ の関係 - 構成関係 式一を通して採り入れられる。パルス光が十分弱けれ ば, 分極と電場の関係は, 線形感受率を用いて 
(a)

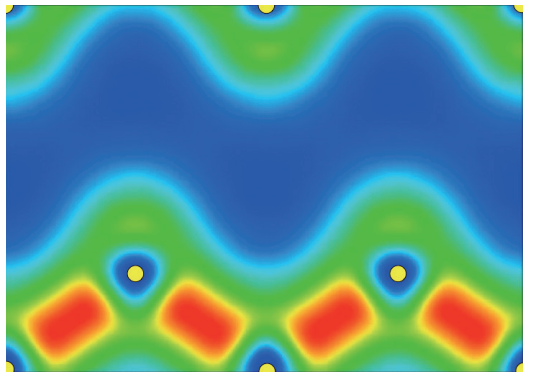

(b)

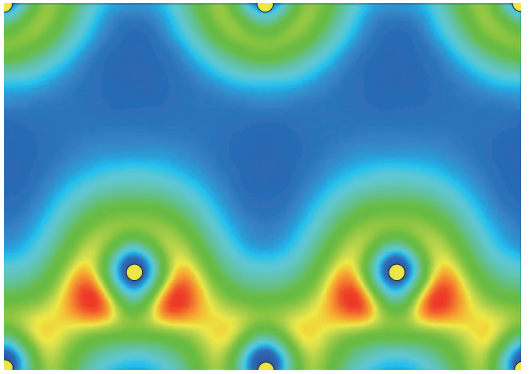

(c)

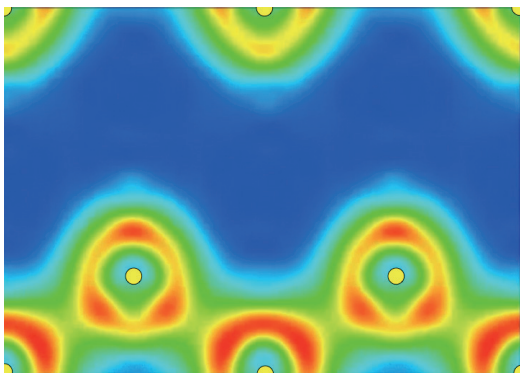

Fig. 2 Electron density distribution of crystalline silicon (a) before, (b) during, and (c) after the laser pulse irradiation.

$$
P(t)=\int_{-\infty}^{t} d t^{\prime} x\left(t-t^{\prime}\right) E\left(t^{\prime}\right)
$$

により記述される。しかしレーザー加工の初期過程で は，物質が瞬時にプラズマ化されることを反映した，電 子の光応答が著しい非線形性を伴う場合の構成関係式が 必要とされる. 従来, このような目的のため, 多光子励 起過程などを経験的に取り入れた電子の運動学的な方程 式とマクスウェル方程式を並行して解き進めるアプロー チが開発されてきた ${ }^{8,9}$. これれ対して我々は, 前章で 述べた電子ダイナミクス計算を, 高強度パルス光の光電 場に対して有効となる数值的な構成関係式として用いる ことで, 光波と電子のダイナミクスを同時に記述する方 法を発展させている7).

前章で述べた電子ダイナミクス計算が構成関係式と見 なせることは, Fig. 1(b)に示した電流を時間で積分する と分極 $P(t)$ を得ることができることから明らかであろ う。（1）式を解いて電子ダイナミクス計算を行えば，任意 の波形と強度を持つパルス電場 $E(t)$ に対して分極 $P(E(t))$ を得ることができる，次にこの考え方のもと，高強度パ ルス光が物質を伝播する様子を記述する方法を考える。

$$
3.2 \text { マクスウェル＋TDDFTマルチスケール計算 }
$$

半無限の誘電体が存在し, その表面が $z=0$ で与えられ るとする $(z<0$ は真空領域 $)$. 直線偏光を持つパルス光 が，真空領域から誘電体に向けて，z方向へ1次元的に伝 播するとする。このパルス光をベクトルポテンシャル $A(Z, t)$ で表現すると, マクスウェル方程式(波動方程式) は,

$$
\frac{1}{c^{2}} \frac{\partial^{2} A}{\partial t^{2}}-\frac{\partial^{2} A}{\partial Z^{2}}=-\frac{4 \pi e}{c} J
$$

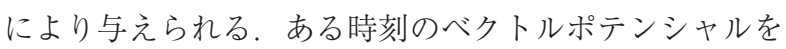
初期值としてこの方程式を解くためには, 空間の各点 $Z$ での電流 $J(Z, t)$ が必要となる。通常の巨視的マクスウェ ル方程式と同様に，局所的な応答を仮定しょう。すなわ ち, 点Zに扔ける電流 $J(Z, t)$ は, 同じ点での電場を与え るベクトルポテンシャル $A(Z, t)$ によって決まるとする.

長波長近似のもと, 空間の各点Zに扔ける電子ダイナ ミクスは(1)式で記述されるものとし，Z点毎に異なる ブロッホ関数 $u_{\mathrm{nn}, Z}(r, t)$ を考元る. 各点で $(1)$ 式を解けば,

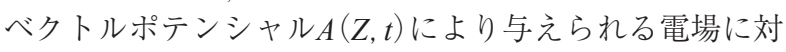
して電流 $J(Z, t)$ を求めることができることが分かる. (1)式には 2 種類の空間座標Zと放現れることになるが, 長波長近似の考え方から，(1)式を解く際にはべクトル ポテンシャル $A(Z, t)$ のZ依存性を無視することにする. 我々はこの枠組みを, マクスウェル＋TDDFT多階層連 結(マルチスケール)計算と呼んでいる.

この枠組みで, パルス光の電場が十分弱く電子の光応 答が量子力学の摂動論により記述される場合には，(3) 式の右辺の電流は電場とTDDFTで得られる電気伝導度 により結びっけられる。従って(3)式と (1) 式を多階層連 結した計算は, 通常の巨視的マクスウェル方程式に帰着 する。このように（3)式と（1)式を連結したマクスウェ ル + TDDFT多階層連結計算は, 弱いパルス光に対して 通常の巨視的マクスウェル方程式を包含する, 沉用性の 高い枠組みとなっている。

\section{3 シリコン結晶を伝播するパルス光計算}

マクスウェル＋TDDFT多階層連結計算の例として, シリコン結晶の表面に垂直に入射する直線偏光パルス光 の計算結果を紹介する77. Fig. 3に, 最大強度 $10^{13} \mathrm{~W} / \mathrm{cm}^{2}$,

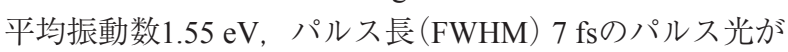
伝播する計算結果を示す，図の左側に3つのベクトルポ テンシャルを座標Zの関数として示す，上はパルス光が 真空領域にある初期条件, 中はパルス光がシリコン表面 に達し一部が侵入しているとき，下はパルス光が反射光 と透過光に別れたあとを示す，右側は，対応する時刻に 抒けるシリコン結晶中の電子の励起エネルギーを示して いる。 パルス光が存在する領域では電子が摇すられてい るために電子励起エネルギーが現れている。最後の時刻 でパルス光が透過した後の領域に, 電子励起エネルギー が残っている. これは, 多光子吸収過程によるパルス光 から物質電子へのエネルギー移行が, 表面で最も強く, 内部に向かい徐々に減衰するよう起きていることを示し ている.

Fig. 4に，強度の異なる4つのパルス光が入射した場合 の計算結果を示す，左側に入射波が反射波と透過波に分 

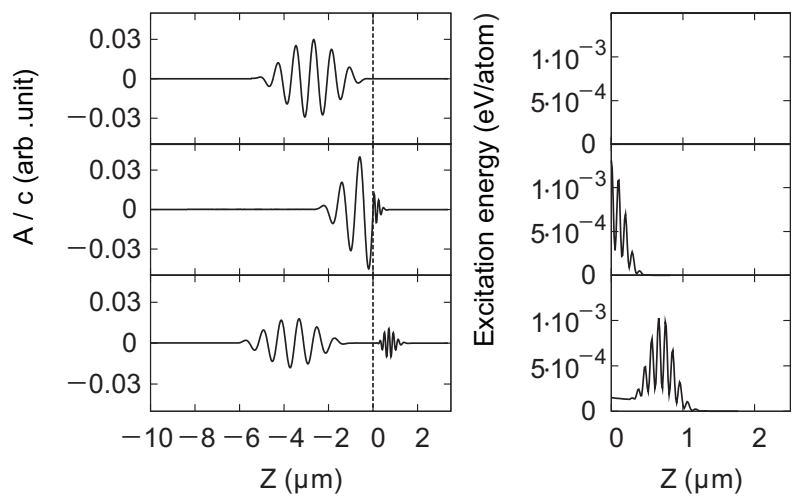

Fig. 3 Maxwell + TDDFT calculation for a propagation of strong laser pulse in crystalline silicon. Left panels show vector potentials and right panels show electron excitation energy as functions of distance from the surface. Taken from7).
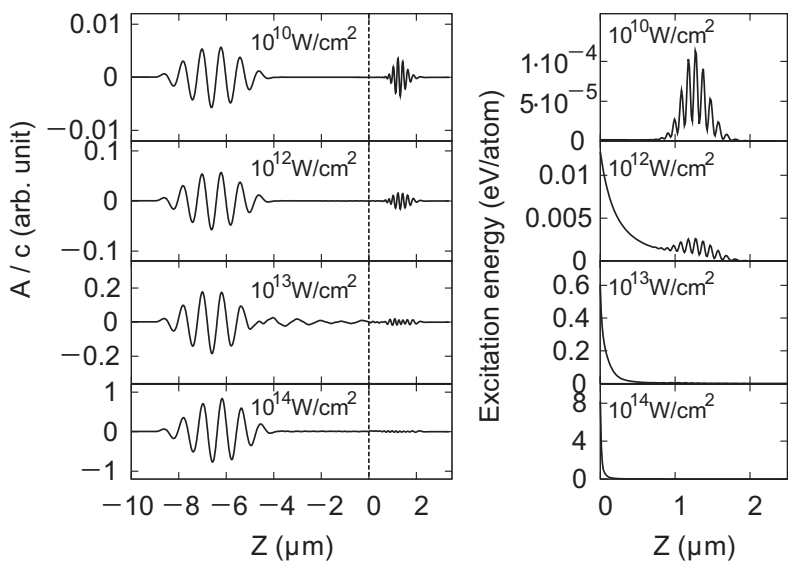

Fig. 4 Maxwell + TDDFT calculations for pulsed lights of different intensities. Left panels show vector potentials when incident pulses are separated into reflected and transmitted waves. Right panels show electron excitation energies. Taken from7).

かれた時刻におけるベクトルポテンシャルを, 右側に電 子の励起エネルギーの空間分布を示している. 弱いパル 久光 $\left(\right.$ 最大強度が $\left.10^{10} \mathrm{~W} / \mathrm{cm}^{2}\right)$ が入射した場合は, 誘電率 を用いた線形応答で記述される状況となっており，入射 波の振動数が直接ギャップエネルギーよりも低いため, パルス光の通過後は, 電子は基底状態に戻っており, 電 子励起エネルギーは0となっている.

入射パルスの強度が増すと, 多光子吸収によるパルス 光から電子へのエネルギー移行が表面で顕著になる。工 ネルギー移行は，拈よそ $1 \mu \mathrm{m}$ 以下の領域で顕著であ る。ベクトルポテンシャルを見ると, 反射波は入射強度 によりあまり変化していないが, 透過波は入射波の強度 とともに著しく減衰している，乙れは，表面で透過光の エネルギーの大部分が電子に移行していることを反映し ている.

\section{4. アブレーションのしきい值・深さの見積もり}

前章までで述べた理論と計算により，パルス光が物質 の表面から入射し数マイクロメートルの距離を移動する 拉よそ数十フェムト秒以内の時間で起こる現象を, 経験 的なパラメー夕を用いることなく記述することができ る. 原子の運動は, 最も速いフォノンの周期が数十フェ ムト秒程度であることから，この時間の範囲ではほぼ無 視できる.

光から電子に移行したエネルギーは, ピコ秒程度の時 間で電子から原子へと移行し，物質の壊変を引き起こ す。我々は簡単化した仮定として, 数十フェムト秒の時 間で光から電子に移行したエネルギーが，その後の過程 で拡散することなくアブレーションなどの加工プロセス を引き起こすと考え，アブレーションのしきい值や表面 からの深さを見積もる解析を， $\alpha$ クォーツ $\left(\mathrm{SiO}_{2}\right)$ を対象 に行った ${ }^{10,11)}$.

計算は, 様々な強度の直線偏光パルス光が $\alpha$ オーツ に垂直に入射するとし, 平均振動数 $1.55 \mathrm{eV}$, パルス長 (FWHM) 7 fsのパルス光に対して行った. Fig. 5にパルス 光から物質電子へのエネルギー移行を，表面からの深さ の関数として示す，パルス光の最大強度が増すにつれ， 徐々にエネルギー移行が表面で顕著となっている。水平 線で， $\alpha$ クーツの1原子あたりの平均の結合エネル ギーと融解エネルギーを示している。周囲への熱拡散を 無視すれば，1原子あたりの電子励起エネルギーが原子 の結合エネルギーを越える前後でアブレーションが起こ ると考えられる。原子がバラバラに放出されるのではな くクラスターとしても放出されることを考えれば，結合 エネルギーとの比較から得られる強度はアブレーション しきい值の上限と考えるべきだろう。このようにして Fig. 5の結果からアブレーションのしきい值を評価する と，打打よそ $1.8 \mathrm{~J} / \mathrm{cm}^{2}$ という值が得られる。

次に, パルス光から物質電子へのエネルギー移行が平 均の結合エネルギーと同程度となることを条件に，アブ レーションの深度を評価した結果をFig. 6に示す. Fig. 5

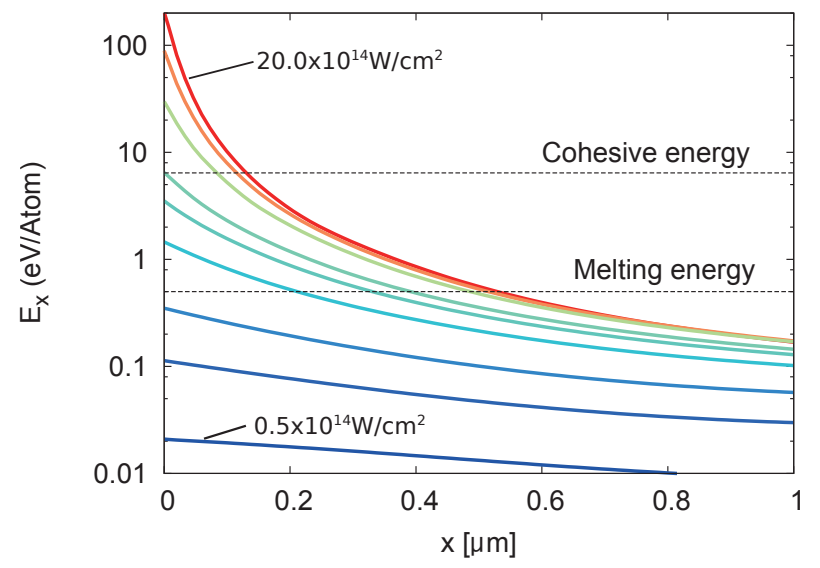

Fig. 5 Energy transfer from laser pulse to electrons in $\mathrm{SiO}_{2}$. Results for laser pulses of intensities, 0.5 , $0.75,1.0,1.5,2.0,2.5,5.0,10.0,20.0 \times 10^{14} \mathrm{~W} / \mathrm{cm}^{2}$ are shown. Taken from10). 


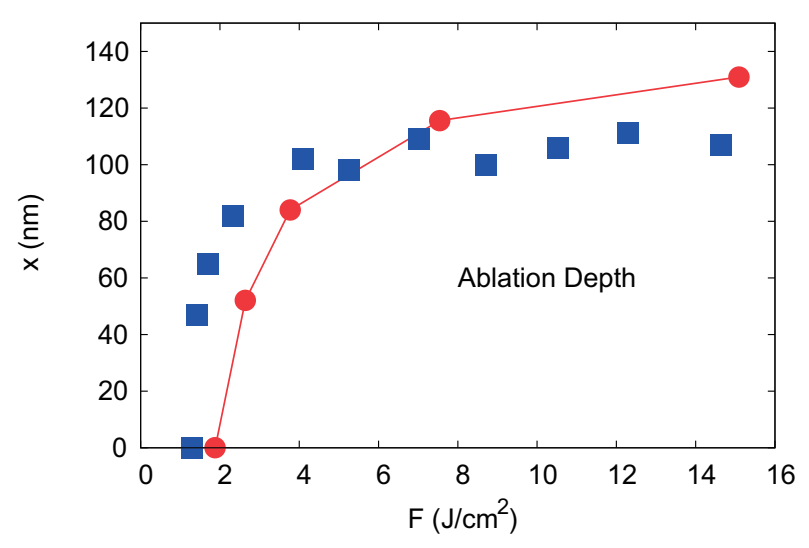

Fig. 6 Depth of ablation crator estimated from the energy transfer from laser pulses to electrons shown in Fig. 5. Squares are measurements ${ }^{12)}$ and circles connected by line are calculations. Taken from10).

を見ると, パルス光の強度を増しても, 結合エネルギー 程度のエネルギー移行が起こる深さは，表面から $100 \mathrm{~nm}$ 程度で飽和している. Fig. 6に, パルス光のフルエンス を横軸に, アブレーションの深さを縦軸に, 実験值 ${ }^{12)}$ と 比較した結果を示している. 実験では, 単一パルスの作 るクレーターの深度は, 強度によらず100 $\mathrm{nm}$ 程度と報 告されているが，我々の第一原理計算による見積りは， おおよそその結果を再現している.

\section{5. 終わりに}

本稿では, パルス光と誘電体の相互作用に対する時間 依存密度汎関数理論に基づく第一原理計算の現状を紹介 した。バンド計算を時間依存に拡張し，巨視的マクス ウェル方程式と結合することにより，数十フェムト秒の
時間スケールで起こるパルス光から物質電子へのエネル ギー移行に対して経験的な要素のない計算が可能となる ことを示した。このエネルギー移行から，アブレーショ ンのしきい值や深さの測定值が, 少なくとも定性的に再 現できることを示した。

最近破壊をもたらす直前の強度でのパルス光と物質の 相互作用を調べる実験研究が進展しており，本稿のアプ ローチはそのような場合にも有用である。例えば，アト 秒科学の方法を用いることにより，パルス光から物質へ の超高速エネルギー移行を直接調べることが可能となっ ている ${ }^{13)}$.

\section{参考文献}

1) C. A. Ullrich: Time-Dependent Density-Functional Theory, Concepts and Applications (Oxford University Press, 2012).

2) 矢花一浩：J. Vac. Soc. Japan 54 (2011) 522.

3) K. Yabana, G. F. Bertsch: Phys. Rev. B 54 (1996) 4484.

4) G. F. Bertsch, J.-I. Iwata, A. Rubio, and K. Yabana: Phys. Rev. B $62(2000) 7998$.

5) K. Yabana, T. Nakatsukasa, J.-I. Iwata, and G. F. Bertsch: Physica Status Solidi (b) 243 (2006) 1121.

6) Y. Shinohara, K. Yabana, Y. Kawashita, J.-I. Iwata, T. Otobe, and G. F. Bertsch: Phys. Rev. B 82 (2010) 115110.

7) K. Yabana, T. Sugiyama, Y. Shinohara, T. Otobe, and G. F. Bertsch: Phys. Rev. B 85 (2012) 045134.

8) G. M. Petrov and J. Davis: J. Phys. B 41 (2008) 025601.

9) E. G. Gamaly: Phys. Rep. 508 (2011) 91.

10) S. A. Sato, K. Yabana, Y. Shinohara, T. Otobe, K.-M. Lee, and G. F. Bertsch: Phys. Rev. B 92 (2015) 205413.

11) K.-M. Lee, C. M. Kim, S. A. Sato, T. Otobe, Y. Shinohara, K. Yabana, and T. M. Jeong: J. Appl: Phys. 115 (2014) 053519.

12) B. Chimier, O. Uteza, N. Sanner, M. Sentis, T. Itina, P. Lassonde, F. Legare, F. Vidal, and J. C. Kieffer: Phys. Rev. B 84 (2011) 094104.

13) A. Sommer, E. M. Bothschafter, S. A. Sato, C. Jakubeit, T. Latka, O. Razskazovskaya, H. Fattahi, M. Jobst, W. Schweinberger, V. Shirvanyan, et al.: Nature 534 (2016) 86. 